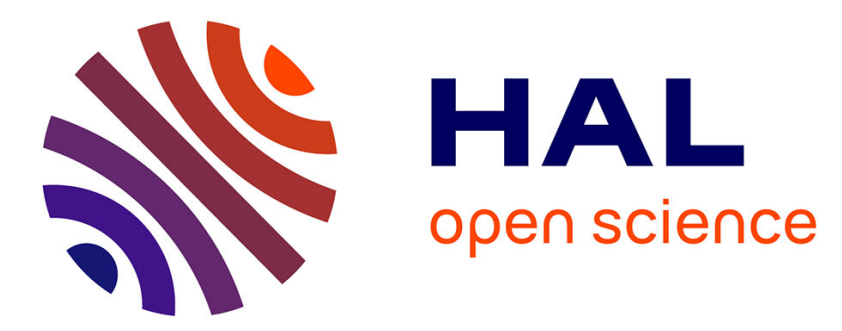

\title{
Electrochemical Behavior of Chemical Vapor Deposited Protective Aluminum Oxide Coatings on Ti6242 Titanium Alloy
}

Grégory Boisier, Monica Raciulete, Diane Samélor, Nadine Pébère, Alain Gleizes, Constantin Vahlas

\section{To cite this version:}

Grégory Boisier, Monica Raciulete, Diane Samélor, Nadine Pébère, Alain Gleizes, et al.. Electrochemical Behavior of Chemical Vapor Deposited Protective Aluminum Oxide Coatings on Ti6242 Titanium Alloy. Electrochemical and Solid-State Letters, 2008, vol. 11, pp.C55-C57. 10.1149/1.2968109 . hal-00806102

\section{HAL Id: hal-00806102 https://hal.science/hal-00806102}

Submitted on 29 Mar 2013

HAL is a multi-disciplinary open access archive for the deposit and dissemination of scientific research documents, whether they are published or not. The documents may come from teaching and research institutions in France or abroad, or from public or private research centers.
L'archive ouverte pluridisciplinaire HAL, est destinée au dépôt et à la diffusion de documents scientifiques de niveau recherche, publiés ou non, émanant des établissements d'enseignement et de recherche français ou étrangers, des laboratoires publics ou privés. 


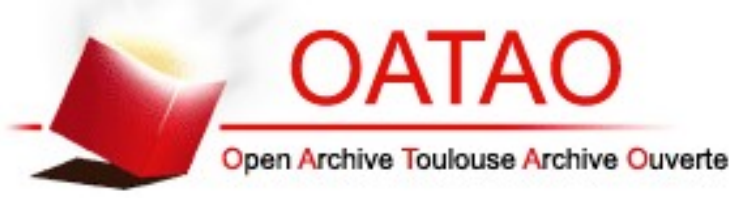

\section{Open Archive Toulouse Archive Ouverte (OATAO)}

OATAO is an open access repository that collects the work of Toulouse researchers and makes it freely available over the web where possible.

This is an author-deposited version published in: http://oatao.univ-toulouse.fr/ Eprints ID : 2433

To link to this article :

URL : http://dx.doi.org/10.1149/1.2968109

To cite this version : Boisier, Grégory and Raciulete, M. and Samélor, D. and Pébère, Nadine and Gleizes, Alain and Vahlas, Constantin ( 2008)

Electrochemical Behavior of Chemical Vapor Deposited Protective Aluminum Oxide Coatings on Ti6242 Titanium Alloy. Electrochemical and Solid State Letters, vol. 11 (n 10). C55-C57. ISSN 1099-0062

Any correspondence concerning this service should be sent to the repository administrator:staff-oatao@inp-toulouse.fr 


\title{
Electrochemical Behavior of Chemical Vapor Deposited Protective Aluminum Oxide Coatings on Ti6242 Titanium Alloy
}

\author{
G. Boisier, ${ }^{*}$ M. Raciulete, D. Samélor, N. Pébère, ${ }^{* *}$ A. N. Gleizes, and C. Vahlas ${ }^{\mathrm{z}}$ \\ Institut Carnot-Centre Interuniversitaire de Recherche et d'Ingénierie des Matériaux, ENSIACET, \\ 31077 Toulouse cedex 04, France
}

\begin{abstract}
The electrochemical behavior at room temperature in a neutral sodium chloride aqueous solution of four types of metallorganic chemical vapor deposited aluminum oxide coatings on commercial Ti6242 titanium alloy was investigated. Polarization and electrochemical impedance curves revealed that porosity free, amorphous alumina coatings provide a two order of magnitude improvement of the corrosion resistance with regard to the bare alloy. Crystallized alumina as well as amorphous $\mathrm{AlO}(\mathrm{OH})$ only slightly improve the corrosion resistance of Ti6242. It was demonstrated that metallorganic chemical vapor deposition processed amorphous alumina is a highly promising solution to the protection of titanium alloys against corrosion in salt environments.
\end{abstract}

[DOI: $10.1149 / 1.2968109$ ]

Ti6242 titanium alloy is a promising material for the manufacturing of helicopter turbine components submitted to moderate stresses and temperatures. In addition to titanium, the alloy contains aluminum $(6 \mathrm{wt} \%)$, tin (2 wt \%), zirconium (4 wt \%), and molybdenum ( 2 wt $\%)$. It is composed of Al-stabilized $\alpha$ phase and of a small amount of Mo-stabilized $\beta$ phase. Tin and zirconium act as hardeners, and combined with aluminum, they render the alloy creep resistant up to $873 \mathrm{~K}$. It can thus be safely used at operating temperatures up to $823 \mathrm{~K}$, provided that it is protected against oxidation. Such protection can be conferred by Al-containing coatings, which are widely used in aeronautic industry, mainly as bond coats to prevent parts such as turbine blades and vanes from excessive oxidation.

Al-containing coatings are mainly processed by the classical pack-aluminization technique. However, the high processing temperature does not allow such processes to be applied on the Ti6242 alloy. Unlike pack-aluminization, metallorganic chemical vapor deposition (MOCVD) operates at low to moderate temperature and yields highly conformal films. Recently, alumina forming metallic coatings, namely $\mathrm{Al}$ and $\mathrm{Al}+\mathrm{Pt}$, were successfully processed on Ti6242 coupons by MOCVD and tested against isothermal oxidation. ${ }^{1,2}$ Alternatively, amorphous $\mathrm{Al}_{2} \mathrm{O}_{3}$ coatings directly applied by MOCVD on Ti6242 were also investigated. They showed promising results for the protection against aggressive atmospheric exposure $^{3}$ and against dry oxidation, namely 20 -fold lower oxidation kinetics than that of the bare alloy. ${ }^{4}$

In the frame of the latter work it was shown that aluminum oxide coatings with different characteristics as a function of the deposition temperature can be processed by the MOCVD route: amorphous $\mathrm{Al}_{2} \mathrm{O}_{3}$ between 623 and $973 \mathrm{~K}$, amorphous oxy-hydroxides and gradually crystallized $\gamma-\mathrm{Al}_{2} \mathrm{O}_{3}$ below and above this temperature range, respectively; ${ }^{5}$ the latter also being obtained after annealing at $1073 \mathrm{~K}$ of amorphous $\mathrm{Al}_{2} \mathrm{O}_{3}{ }^{6}$

The present work deals with the investigation of the electrochemical behavior at room temperature in a neutral sodium chloride aqueous solution of such four different types of aluminum oxide coatings applied on Ti6242 coupons. The objective is to correlate the electrochemical results with the microstructure of the coatings and ultimately with their barrier properties. The deposition conditions and the microstructure of the coatings are recalled first, followed by the presentation of the electrochemical tests. Finally, the electrochemical results (polarization curves and impedance diagrams) are presented and discussed.

\footnotetext{
* Electrochemical Society Student Member.

** Electrochemical Society Active Member.

${ }^{z}$ E-mail: constantin.vahlas@ensiacet.fr
}

\section{Experimental}

Sample preparation.- The MOCVD setup consisted of an instrumented horizontal, $2.54 \mathrm{~cm}$ in diameter, hot wall reactor and has been previously described. ${ }^{6}$ Depositions were performed on Ti6242 disks with diameter and thickness of 15 and $2 \mathrm{~mm}$, respectively. The substrates were polished down to $0.25 \mu \mathrm{m}$ with diamond paste, which provided mirror-like surface finishing. Aluminum triisopropoxide (ATI, Across Organics) was used as precursor for the deposition of aluminum oxide films. ${ }^{7}$ It was melted in its bubbler above $413 \mathrm{~K}$ and was kept as a supercooled liquid at $383 \mathrm{~K}$ during deposition. ${ }^{5}$ Total pressure $0.67 \mathrm{kPa}(5 \mathrm{Torr}), \mathrm{N}_{2}$ flow rate bubbling through ATI at 53 standard centimeters per minute $(\mathrm{sccm})$ and dilution $\mathrm{N}_{2}$ flow rate at $653 \mathrm{sccm}$ were kept constant for all experiments. Complementary information on processing conditions for reported experiments is provided in Table I. Sample R19 was postdeposition annealed in a sealed quartz tube in vacuum. Gleizes et al. ${ }^{5}$ showed that the adopted conditions provide amorphous (R17), poorly crystallized (R22), and crystallized (R19) alumina films, whereas the lowest deposition temperature (R20) provides amorphous films of formula $\mathrm{AlO}(\mathrm{OH})$.

Films thickness was estimated by optical reflectometry using a NC-UV-VIS reflectometer (Ocean Optics) and the Nanocalc software. Calibration of the instrument was performed by using an uncoated Ti6242 sample with the same surface preparation.

Electrochemical tests. - The samples were characterized by voltammetry and electrochemical impedance spectroscopy. A threeelectrode cell was used for the experiments: the coated or uncoated Ti6242 coupons as working electrode with an exposed area of $1 \mathrm{~cm}^{2}$, a saturated calomel reference electrode (SCE) and a platinum grid as auxiliary electrode. Experiments were performed in a $0.1 \mathrm{M}$ $\mathrm{NaCl}$ solution at room temperature without stirring. Electrochemical measurements were carried out using a Solartron 1287 electrochemical interface and a 1250 frequency response analyzer. The impedance diagrams were performed under potentiostatic regulation at the corrosion potential after $1 \mathrm{~h}$ of immersion in the $\mathrm{NaCl}$ solution and over a frequency range of $65 \mathrm{kHz}$ to $20 \mathrm{mHz}$ with 6 points per decade. The polarization curves were obtained after the impedance measurements from cathodic to anodic potentials. The potential sweep rate was fixed at $0.277 \mathrm{mV} \mathrm{s}^{-1}$. One measurement was realized on each sample. This is not sufficient to unambiguously validate the obtained quantitative information. However, it can be pointed out that the controlled and reproducible microstructure of each film allows, at least, a qualitative ranking of the samples with regard to their electrochemical behavior.

\section{Results and Discussion}

Samples with comparable thickness of 200-300 nm were targeted. Estimated thickness values reported in Table I vary between $200 \mathrm{~nm}$ and $350 \mathrm{~nm}$. This discrepancy is attributed to the evolution 


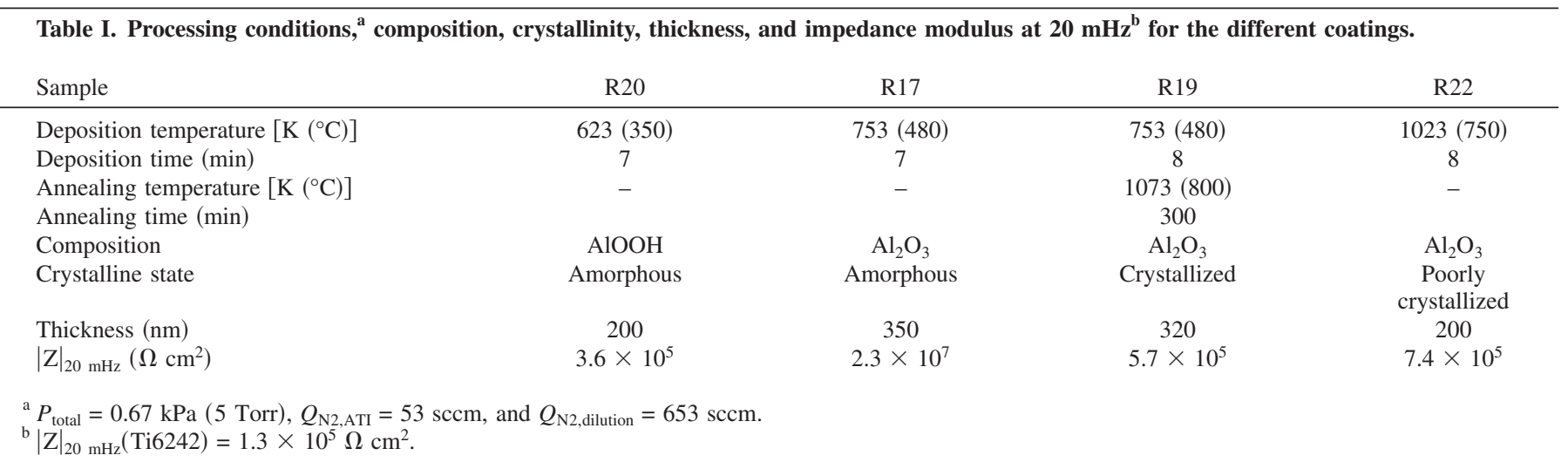

of the precursor characteristics during storage and operation ${ }^{7}$ and to the short deposition time used; i.e., between 7 and $8 \mathrm{~min}$, with regard to the duration of the transient regimes of the deposition protocol.

Table I also resumes the differences in composition and crystallinity of the four samples. From infrared spectroscopy, X-ray diffraction, electron probe microanalysis, energy dispersive X-ray analysis, elastic recoil detection analysis, Rutherford backscattering spectroscopy techniques, and thermal gravimetric analysis, it has been shown ${ }^{5}$ that deposition at $623 \mathrm{~K}$ from ATI provides amorphous, hydroxylated films whose elemental composition fits the formula $\mathrm{AlO}(\mathrm{OH})$. The other three deposits that were prepared above $688 \mathrm{~K}$ are composed of pure $\mathrm{Al}_{2} \mathrm{O}_{3}$. Depending on deposition temperature they are amorphous (753 K), poorly crystallized (1023 K), and well crystallized (after annealing at $1073 \mathrm{~K}$ ). ${ }^{5}$

The polarization curves obtained for the uncoated Ti6242 alloy and for the four different films deposited on Ti6242 are presented in Fig. 1. Sample R20 shows approximately the same corrosion potential as the bare alloy, whereas samples R17, R19, and R22 show higher corrosion potentials. Sample R17 presents the lowest cathodic and anodic current densities and is the only one that shows a stable passivation regime in the anodic domain. For the other samples, the anodic current density progressively increases as the potential increases. This indicates that coatings R19, R20, and R22 provide lower protection against corrosion than R17. For coating R19, the anodic branch first tends to plateau and then shows a sharp increase of the anodic current density at a potential of about $0.4 \mathrm{~V} / \mathrm{SCE}$. This phenomenon corresponds to a localized process probably due to a breakdown of the coating. For R20, it can be observed that the current densities are lowered similarly in the anodic and cathodic range, which could be explained by a decrease of the active area. For R22, the cathodic current densities are close to those obtained for the bare alloy. The anodic current densities are lower than those measured on Ti6242, but no plateau is observed showing that the coating is poorly protective.

The electrochemical impedance diagrams obtained after $1 \mathrm{~h}$ of immersion in a $0.1 \mathrm{NaCl}$ solution, for the uncoated Ti6242 and for the four different films deposited on Ti6242 are presented in Bode coordinates in Fig. 2: magnitude of the impedance (Fig. 2a) and phase angle (Fig. 2b). From the low frequency part of the diagrams, it can be seen that coating R17 stands out by improving the corrosion resistance of nearly two orders of magnitude in comparison with the uncoated sample (impedance modulus at $20 \mathrm{mHz}$ for the different samples is provided in Table I). Contrastingly, films R19, R20, and R22 slightly improve the corrosion resistance of the bare alloy (Table I). The impedance diagram for R19 is characterized by a single time constant and is relatively similar to that obtained for the bare alloy. Thus, the protection afforded by the R19 coating is negligible. On the contrary, the three other samples show impedance diagrams with the presence of a new time constant in the high frequency range which is characteristic of the coating. Sample R20 clearly presents two well-defined time constants (illustrated in Fig. 2b) which account for the existence of pores in the coating. Coating porosity allows diffusion of the electrolyte to the substrate. This corroborates the fact, deduced from the polarization curves, that the corrosion processes occur on a reduced area. Similarly, sample R22 is also characterized by two time constants, which, however, are not well-defined. Thus, it can be assumed that this coating contains a large number of defects, which considerably decrease its barrier properties and can explain the result shown by the polarization curves. The impedance diagram obtained for R17 exhibits a plateau in the HF range (Fig. 2b) with a value close to $-90^{\circ}$, which indicates the presence of a porosity free protective layer (insulating coating). Thus, this coating provides the best protection in agreement with the very low current densities measured on the polarization curve (Fig. $1)$.

It is known that the thickness of the coating influences corrosion performance. For example, Guidi et $\mathrm{al}^{8}{ }^{8}$ showed that a $2.40 \mu \mathrm{m}$ thick, MOCVD processed $\mathrm{Al}_{2} \mathrm{O}_{3}$ coating ensures better protection against corrosion than a $0.31 \mu \mathrm{m}$ thick one. In the present study, the thickness variation of the four coatings is less than twofold. Consequently, only the oxide microstructure (crystalline state, chemical composition) and the presence of defects (such as pores) in the coatings are taken into account for a better understanding of the corrosion behavior observed for the different systems. ${ }^{9}$ Both R17 and R20 coatings are amorphous but chemically different (vide supra). The $\mathrm{R} 17$ coating prepared at $753 \mathrm{~K}$ is composed of $\mathrm{Al}_{2} \mathrm{O}_{3}$ and is exempt of porosity. The composition of R20 prepared at $623 \mathrm{~K}$ is $\mathrm{AlO}(\mathrm{OH})$. Crystallized $\mathrm{AlO}(\mathrm{OH})$ is known to have a layered structure. ${ }^{\mathrm{i}, 11}$ Amorphous $\mathrm{AlO}(\mathrm{OH})$ most likely contains short range layered structure domains rendering coating R20 somewhat porous at the nanoscale. A film prepared in the same conditions has been

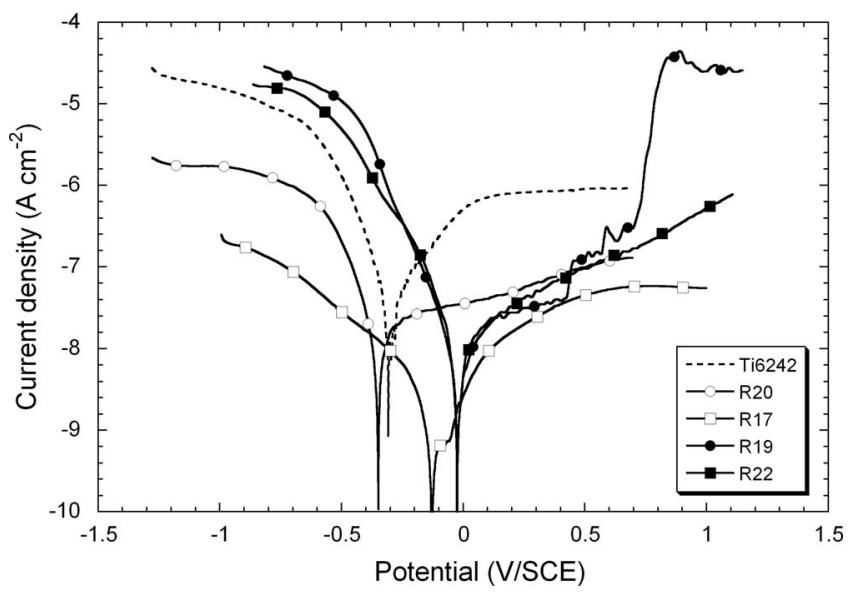

Figure 1. Polarization curves for the bare Ti6242 alloy and for the four different aluminum oxide coatings plotted from cathodic to anodic potentials in $0.1 \mathrm{M} \mathrm{NaCl}$ solution [non-coated Ti6242 (---), R20 (○), R17 ( $\square)$, R19 (), and R22 (ם)]. 

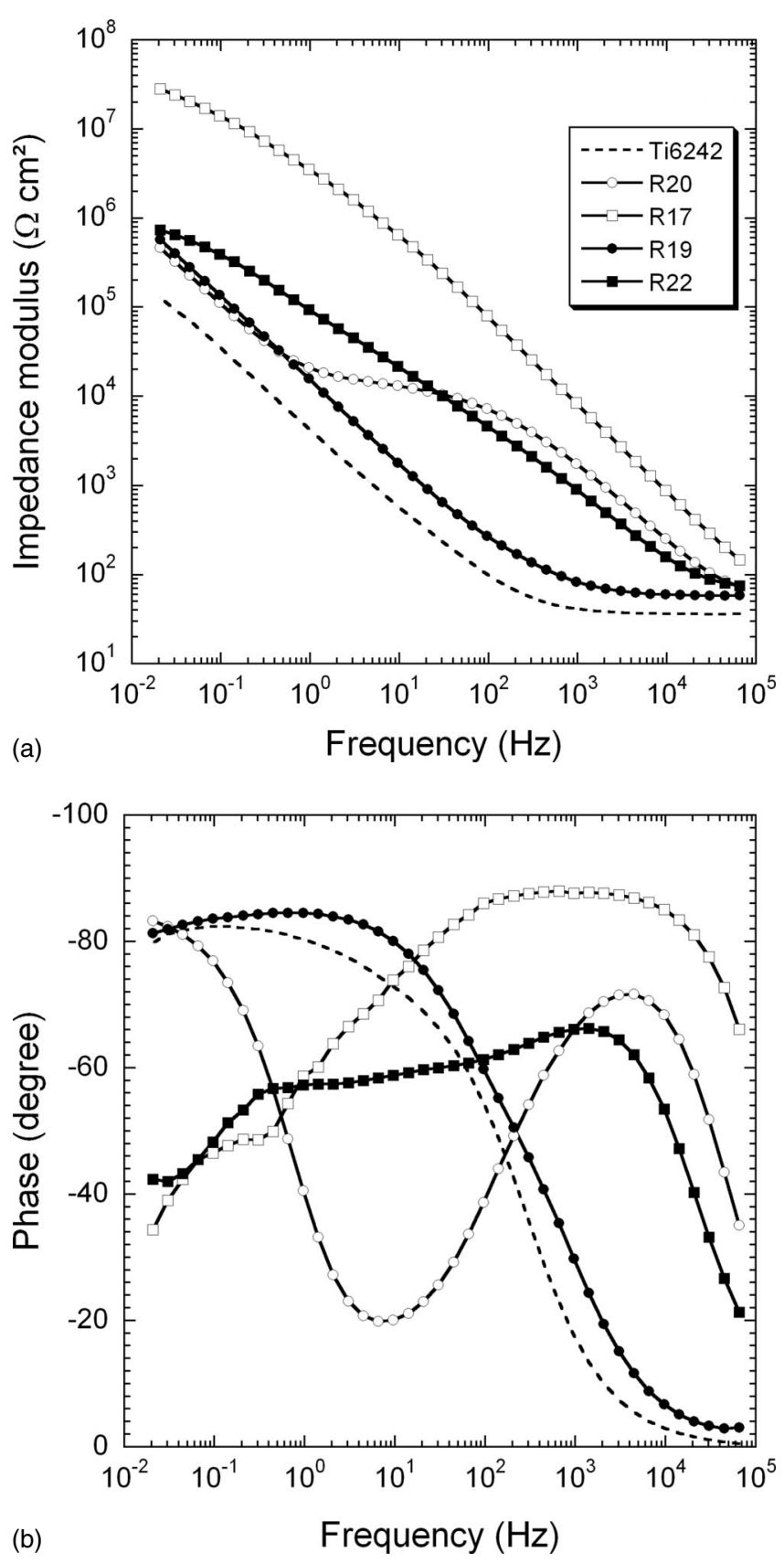

Figure 2. (a) Impedance modulus and (b) phase of the bare Ti6242 and of the four different aluminum oxide coatings, [bare Ti6242 (---), R20 (O), R17 $(\square)$, R19 (๑), and R22 ( $)$ ] (obtained after $1 \mathrm{~h}$ of immersion in $0.1 \mathrm{M} \mathrm{NaCl}$ solution).

shown to most likely absorb water when maintained in ambient air. ${ }^{5}$ Moreover, the presence of the hydroxo groups may lead to reduced chemical stability in chloride-containing aqueous solution with subsequent decrease of the protection against corrosion as was presently observed from the electrochemical results.
Film R19 consists of well crystallized alumina obtained by annealing the as-deposited amorphous structure at $1073 \mathrm{~K}$. In this case, microstructure features, such as grain boundaries, may favor electrolyte penetration thus decreasing the barrier properties of the coating. Film R22 consists of poorly crystallized alumina. Its efficiency against corrosion is comparable to that of R19. However, the impedance diagram for $\mathrm{R} 22$ revealed the presence of a time constant in the HF range. This behavior might originate from the intermediary state between amorphous and well crystallized alumina.

Optical microscopy observations were performed to assess the surface damages after the electrochemical tests. These observations (not shown) corroborate the electrochemical results. Film R17 revealed an unaffected surface after the anodic polarization, whereas localized attacks were observed for the R19 coating.

\section{Conclusion}

Polarization curves and electrical impedance measurements were used to evaluate the corrosion resistance of bare and aluminum oxide coated Ti6242 commercial titanium alloy in a neutral sodium chloride aqueous solution. Crystallized alumina containing coatings provide poor corrosion protection due to the presence of grain boundaries which favor electrolyte penetration through the film. Amorphous $\mathrm{AlO}(\mathrm{OH})$ coatings also provide limited corrosion protection due to their lamellar nanostructure and to the presence of reactive hydroxo groups. In contrast, porosity free, amorphous $\mathrm{Al}_{2} \mathrm{O}_{3}$ insulating coatings allow for a two order of magnitude improvement of the corrosion resistance with regard to the bare alloy. It is demonstrated that MOCVD processed amorphous alumina from ATI is a highly promising solution for the protection of titanium alloys against corrosion in salt environments.

This communication is aimed to establish a preliminary electrochemical characterization of aluminum oxide films of various compositions and microstructures. A higher number of measurements and correlation of the film thickness with the electrochemical impedance spectroscopy and de characteristics should allow for the consolidation of the results reported.

Centre National de Recherche Scientifique assisted in meeting the publication costs of this article.

\section{References}

1. M. Delmas, D. Poquillon, Y. Kihn, and C. Vahlas, Surf. Coat. Technol., 200, 1413 (2005).

2. M. Delmas, M. Ucar, L. Ressier, M. Pons, and C. Vahlas, Surf. Coat. Technol., 188, 49 (2004).

3. J. D. Béguin, D. Adrian, J. A. Petit, J. P. Rivière, C. Vahlas, and S. Vaillant, Surface Modification Technologies XX, In press.

4. D. Poquillon, L. Presmanes, B. Duployer, J. P. Bonino, B. Daffos, L. Arurault, C. Vahlas, and M. Delmas, Final Report, APROSUTIS project no. 02 K0298, supported by the Réseau National Matériaux et Procédés (RNMP) network (2005).

5. A. Gleizes, C. Vahlas, M. M. Sovar, D. Samélor, and M. C. Lafont, Chem. Vap. Deposition, 13, 23 (2007)

6. D. Samélor, M. M. Sovar, A. Stefanescu, A. N. Gleizes, P. Alphonse, and C. Vahlas, in 15th European Conference on Chemical Vapor Deposition, A. Devi, R. Fischer, H. Parala, M. D. Allendorf, and M. L. Hitchman, Editors, PV 2005-09, p. 1051, The Electrochemical Society Proceedings Series, Pennington, NJ (2005).

7. M. M. Sovar, D. Samélor, A. N. Gleizes, and C. Vahlas, Surf. Coat. Technol., 201, 9159 (2007).

8. F. Guidi, G. Moretti, G. Carta, M. Natali, G. Rossetto, Z. Pierino, G. Salmaso, and V. Rigato, Electrochim. Acta, 50, 4609 (2005).

9. E. J. Lee and S. I. Pyun, Corros. Sci., 37, 157 (1995).

10. B. C. Lippens and J. H. de Boer, Acta Crystallogr., 17, 1312 (1964).

11. W. O. Milligan and J. L. McActee, J. Phys. Chem., 60, 273 (1956). 